Collection/Special issue: COST action FP1202

"Strengthening conservation: a key issue for adaptation of marginal/peripheral populations of forest trees to climate change in Europe (MaP-FGR)"

Guest Editors: Fulvio Ducci, Kevin Donnelly

\title{
Patterns of genetic diversity in European beech (Fagus sylvatica L.) at the eastern margins of its distribution range
}

\author{
Elena Ciocîrlan ${ }^{(1)}$, \\ Nicolae Sofletea ${ }^{(1)}$, \\ Fulvio Ducci ${ }^{(2)}$, \\ Alexandru Lucian Curtu ${ }^{(1)}$
}

\begin{abstract}
Populations located at the periphery of the species' distribution range may play an important role in the context of climate change. These peripheral populations may contain specific adaptations as a result of extreme environmental conditions. The aim of this paper was to assess within population genetic diversity and among population differentiation in one of the most important forest tree species in Europe, European beech (Fagus sylvatica), at the eastern margins of its natural range. We analysed four peripheral, isolated populations and five core populations from the continuous natural range along the Carpathian Mountains using a set of microsatellite markers. Higher levels of genetic diversity as measured by allelic richness (7.34 vs. 6.50) and observed heterozygosity $(0.71$ vs. 0.59$)$ were detected in core populations than in peripheral ones. Population differentiation was slightly higher among peripheral populations than among core, Carpathian populations. There was strong evidence of bottleneck effects in two out of the four peripheral, isolated populations. Both core, Carpathian populations and peripheral, lowlands populations share the same chloroplast haplotype suggesting a common geographical origin from the putative Moravian refuge area. Past long distance founding events with material from the Carpathian mountain chain might explain the occurrence of small, isolated beech populations towards the steppe in the south-east of Romania. Our genetic data may contribute to a better understanding of the evolutionary history of the remnants of beech scattered occurrences at the eastern margins of species' distribution range.
\end{abstract}

Keywords: Fagus sylvatica, Genetic Diversity, Peripheral Populations, Bottleneck Effect ripheral populations are typically smaller and isolated from the continuous distribution range of the species and, as a result, are likely to experience increased genetic drift and to receive less immigrants than core populations (Channell \& Lomolino 2000). Moreover, peripheral populations at the warmer margins of the species distribution may experience higher selection pressure exerted by the warmer climate and thus harbor valuable adaptations. Lower
(1) Department of Forest Sciences, Transilvania University of Brasov, Sirul Beethoven-1, 500123 Brasov (Romania); (2) CREA SEL, Consiglio per la ricerca in agricoltura e l'analisi dell'economia agraria, Forestry Research Centre, I-52100 Arezzo (Italy)

@ Alexandru Lucian Curtu (lucian.curtu@unitbv.ro)

Received: Mar 29, 2017 - Accepted: Aug 23, 2017

Citation: Ciocîrlan E, Sofletea N, Ducci F, Curtu AL (2017). Patterns of genetic diversity in European beech (Fagus sylvatica L.) at the eastern margins of its distribution range. iForest 10: $916-922$. - doi: 10.3832/ifor2446-010 [online 2017-12-07]

Communicated by: Fulvio Ducci neutral genetic variation as well as higher differentiation rates are expected in peripheral, isolated populations than in core populations from the continuous distribution range (Eckert et al. 2008). In addition to climate change, peripheral tree populations may be affected by human activities, such as browsing by cattle, deforestation, and improper forest management.

So far, there are a limited number of studies on genetic diversity of peripheral versus core populations of forest tree species. Significantly higher allelic and genotypic diversity in peripheral populations than in core populations was reported in Eastern white pine (Chhatre \& Rajora 2014). However, similar values for heterozygosity across peripheral and core populations were observed in the same study as well as in Scots pine (Wójkiewicz et al. 2016), eastern white cedar (Pandey \& Rajora 2012) and Sitka spruce (Gapare et al. 2005). Evidence of bottlenecks was reported in peripheral populations of Sitka spruce but not in Scots pine populations. Generally, the differences between peripheral and core populations as estimated using neutral genetic 


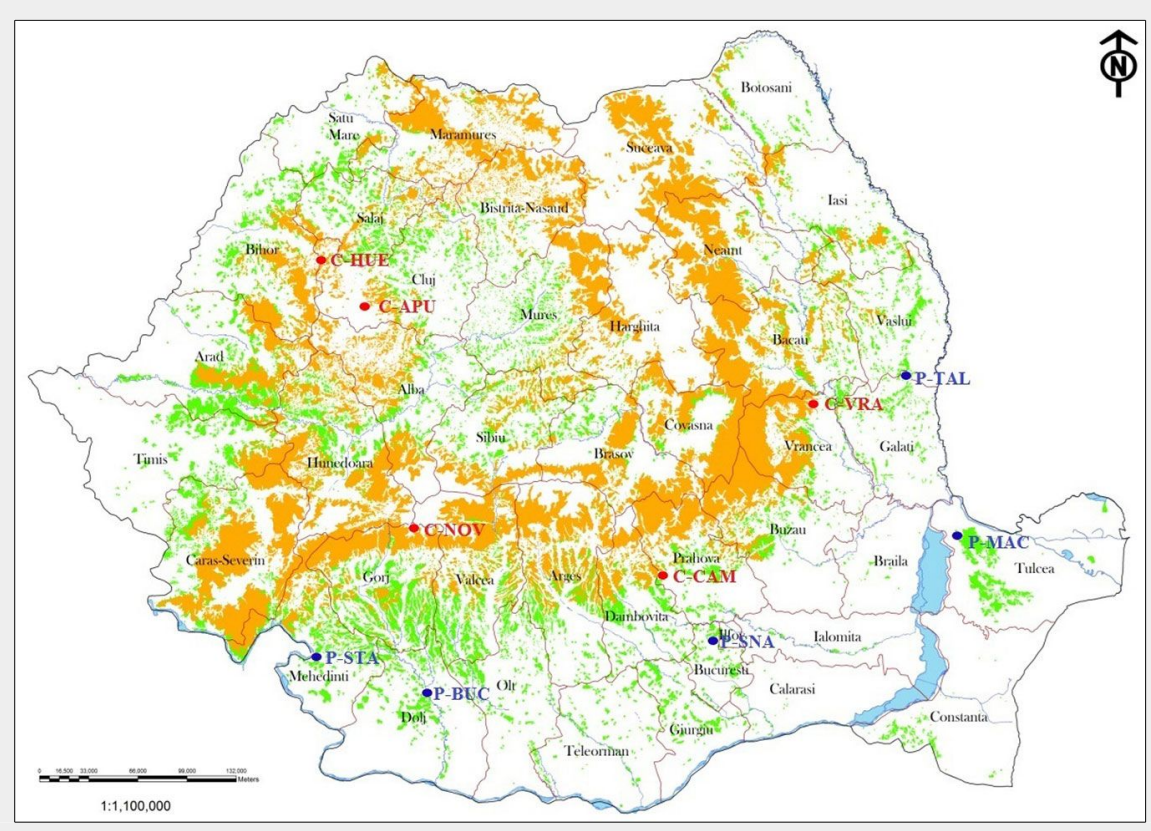

Fig. 1 - Geographic location of the sampled beech populations. (P): peripheral; (C): core. Abbreviations and geographic coordinates of the populations are given in Tab. 1. (Orange area): continuous range of European beech in the Carpathian Mountains; (green area): oak forests.

markers were statistically significant only for certain diversity indices which vary from one study to another.

In this study, we focused on common beech (Fagus sylvatica), one of the most important forest trees in Europe. Common beech occupies about 21 million hectares (Forest Europe/UNECE/FAO 2011) and plays a crucial role for the society, economy and environmental health. It is also a keystone species that fulfills central functions within its ecosystems and interacts with hundreds of associated plant, animal and fungal species. At present, it is the most common forest tree species in Romania, occupying approximately $33 \%$ of the forest area and representing $40 \%$ of the growing stock (Biris 2014). Unlike in western and central Europe, beech was not planted for forestry purposes in Romania and, consequently, the current populations are autochthonous (Stanescu et al. 1997). Only a few studies included samples of beech from Romania
(Comps et al. 1990, Gömöry et al. 2003, Magri et al. 2006) and no investigation was done on peripheral, small, disjunct populations from the south-eastern part of the country where European beech reaches the eastern edge of its range (Stanescu et al. 1997). The most isolated peripheral beech population is located close to the Danube Delta, in the old Macin Mountains (maximum altitude: $467 \mathrm{~m}$ a.s.l.) formed in the second part of Paleozoic, during the Hercynian orogeny. This population grows only along a deep valley and on a north facing slope, and might be of Tertiary origin (Georgescu 1928). A Balkan origin of this particular beech population was also assumed (Diaconeasa 1977). This is in contrast with the geographical origin of existing beech populations in the nearby Carpathian Mountains, which may originate from the Moravian refugium. A secondary refugium might have been in Apuseni Mountains (western Romania), but did not contribute to the colonization of the Carpathians (Magri et al. 2006).

Understanding the evolutionary history of these peripheral beech populations, which are currently threatened by climate change and human activities, can help undertake appropriate management and conservation measures.

In this study, we assessed the genetic diversity of European beech at its eastern margins of the distribution range using a set of microsatellite markers. The specific questions of this paper are: (i) Is within population genetic diversity lower and population differentiation higher in peripheral, isolated populations than in core populations from the continuous Carpathian range? (ii) Is there any evidence based on chloroplast DNA variation of a different geographical origin of existing peripheral and core populations? (iii) Do peripheral, isolated populations show a significant bottleneck signature?

\section{Material and methods}

\section{Study site and sampling}

Our analysis included nine populations of European beech sampled throughout the natural range of the species in Romania (Fig. 1). The sampled populations were grouped into two categories (Tab. 1): four peripheral, isolated populations (P-MAC, $\mathrm{P}$ SNA, P-STA and P-TAL) and five core populations (C-HUE, C-APU, C-NOV, C-CAM and C-VRA). The core populations are located on both sides of the South-Eastern Carpathian Mountains in the continuous natural range of beech. We also sampled the last four remaining living individuals from a small, isolated beech population (Bucovat, P-BUC) located in the lowlands of southern Romania (Fig. 1). Two peripheral populations (P-SNA and P-TAL) were sampled exhaustively. Material was collected from 50 individual trees in the remaining populations. The sampled individuals were at least $30 \mathrm{~m}$ apart in the populations that were not exhaustively sampled. A total of 462 individual trees were sampled in 2012. Only three randomly chosen beech individuals per population, except for population P$M A C$ with five individuals, were analyzed at

Tab. 1 - Geographic location, sample size and climate conditions of the sampled beech populations. Sampling of all remaining trees was done in two populations (P-SNA and P-TAL). (P): peripheral; (C): core.

\begin{tabular}{llcccccc}
\hline Label & Population & $\begin{array}{c}\text { No. of } \\
\text { samples }\end{array}$ & Latitude N & Longitude E & $\begin{array}{c}\text { Altitude } \\
(\mathrm{m})\end{array}$ & $\begin{array}{c}\text { Annual average } \\
\text { temperature } \\
\left({ }^{\circ} \mathrm{C}\right)\end{array}$ & $\begin{array}{c}\text { Annual } \\
\text { rainfall (mm) }\end{array}$ \\
\hline P-MAC & Macin & 100 & $45^{\circ} 16^{\prime}$ & $28^{\circ} 10^{\prime}$ & 125 & 10.5 & 479 \\
P-SNA & Snagov & 37 & $44^{\circ} 43^{\prime}$ & $26^{\circ} 09^{\prime}$ & 92 & 10.6 & 585 \\
P-STA & Stârmina & 50 & $44^{\circ} 29^{\prime}$ & $22^{\circ} 45^{\prime}$ & 77 & 10.4 & 591 \\
P-TAL & Talasmani & 21 & $46^{\circ} 07^{\prime}$ & $27^{\circ} 50^{\prime}$ & 230 & 9.4 & 538 \\
C-HUE & Huedin & 50 & $46^{\circ} 58^{\prime}$ & $22^{\circ} 43^{\prime}$ & 446 & 8.7 & 672 \\
C-APU & Apuseni & 50 & $46^{\circ} 40^{\prime}$ & $23^{\circ} 01^{\prime}$ & 1130 & 5.9 & 821 \\
C-NOV & Novaci & 50 & $45^{\circ} 13^{\prime}$ & $23^{\circ} 40^{\prime}$ & 560 & 8.3 & 702 \\
C-CAM & Câmpina & 50 & $45^{\circ} 06^{\prime}$ & $25^{\circ} 43^{\prime}$ & 520 & 8.3 & 673 \\
C-VRA & Vrancea & 50 & $46^{\circ} 05^{\prime}$ & $27^{\circ} 01^{\prime}$ & 315 & 9.6 & 559 \\
\hline
\end{tabular}


chloroplast DNA level. The material consisting of buds or leaves was stored at $-60{ }^{\circ} \mathrm{C}$ before further analyses.

\section{Genotyping}

DNA was extracted from buds or leaves using the cetyltrimethyl ammonium bromide (CTAB) method (Doyle \& Doyle 1990). DNA concentration and purity were determined spectrophotometrically with a Nanodrop 8000. Seven gSSRs originally developed for F. sylvatica (FS3-04, FS4-46, Mfs11 Pastorelli et al. 2003, Vornam et al. 2004) and F. crenata (Sfco018, Sfc0161, Sfc1063 and Sfc1143 - Asuka et al. 2004) and one EST-SSRs (Fir065) originally developed for Quercus spp. (Durand et al. 2010) were used. FS4-46 was excluded from further analysis because of some ambiguities in its interpretation and due to the presence of a large number of null alleles. Polymerase chain reaction (PCR) was carried out in Corbett and Eppendorf Thermal Cyclers. The amplification was performed in $10 \mu \mathrm{L}$ of reaction mixture consisting of: $5 \times$ PCR Buffer (Promega), $0.2 \mathrm{mM}$ each of dNTP, $2.5 \mathrm{mM}$ $\mathrm{MgCl}, 0.4-0.5 \mu \mathrm{M}$ each of primers and 1.0 $\mathrm{U}$ of Taq DNA polymerase (Promega). The PCR profile was as follows: 15 minutes of initial denaturation at $95^{\circ} \mathrm{C}$ followed by 30 cycles of 1 min denaturation at $94{ }^{\circ} \mathrm{C}$, a $30 \mathrm{~s}$ annealing step at $47{ }^{\circ} \mathrm{C}$ (for multiplex 2 Mfs11, Firo65, FS4-46 and SfC1143) or $55{ }^{\circ} \mathrm{C}$ (for multiplex 1 - Sfc0018, Sfc0161, Sfc1063 and FS3-04), a 1 min elongation step at $72{ }^{\circ} \mathrm{C}$ and a $20 \mathrm{~min}$ final extension step at $72^{\circ} \mathrm{C}$.

Three polymorphic chloroplast microsatellites (ccmp-4, ccmp-7 and ccmp-10) were also amplified. The PCR reactions and performed in a $15 \mu \mathrm{L}$ volume containing $5^{\times}$ PCR Buffer (Promega), $2 \mathrm{mM} \mathrm{MgCl}, 0.2$ $\mathrm{mM}$ dNTPs, $0.3 \mu \mathrm{M}$ of each primer, 0.25 units of Promega Taq DNA polymerase. The PCR protocol consisted of one cycle of initial denaturation at $94{ }^{\circ} \mathrm{C}$ for $15 \mathrm{~min}$, followed by 35 cycles (ccmp-7 and ccmp-10) or 30 cycles (ccmp-4) of denaturation at $94{ }^{\circ} \mathrm{C}$ for $1 \mathrm{~min}$, annealing at $50{ }^{\circ} \mathrm{C}$ for $1 \mathrm{~min}$, and extension at $72{ }^{\circ} \mathrm{C}$ for $1 \mathrm{~min}$. A final extension cycle at $72{ }^{\circ} \mathrm{C}$ for $10 \mathrm{~min}$ followed. Amplified $P C R$ products were diluted and were than run on a GemoneLab GeXP Genetic Analyser $^{\oplus}$ using Frag-3 method and Size Standard 400. The products were further analyzed using Fragment Analysis Software using default parameters and PA ver. 1.0 dye correction.

Microsatellite markers were tested for genotyping errors due to large allele dropout, scoring of stutter peaks and non-amplified alleles using Micro-Checker ${ }^{\circledast}$ ver. 2.2.0.3 (Van Oosterhout et al. 2004). The software indicated the presence of null alleles at very low frequencies (less than $2 \%$ ) for three markers (Sfco018, SfC0161 and Firo65) in only two populations (C-APU and C-NOV). No evidence of large allele dropout or scoring of stutter peaks was found in the populations.



Fig. 2 - Matrix of pairwise genetic differentiation $\left(\mathrm{F}_{\mathrm{ST}}\right)$ among beech populations.

\section{Genetic diversity and differentiation}

The software GenAlEx ${ }^{\oplus}$ ver. 6.5 (Peakall \& Smouse 2006) was used to estimate allele frequencies and standard genetic diversity indices: average number of alleles per locus $\left(\mathrm{N}_{\mathrm{a}}\right)$, effective number of allele $\left(\mathrm{N}_{\mathrm{e}}\right)$, observed heterozigosity $\left(\mathrm{H}_{\mathrm{o}}\right)$, expected heterozigosity $\left(\mathrm{H}_{\mathrm{e}}\right)$ and fixation index $(\mathrm{F})$. Allelic richness $\left(A_{R}\right)$, a measure that is independent of sample size, was estimated with FSTAT ver. 2.9.3 (Goudet 1995). Student's $t$-test was used to examine differences between mean values of genetic diversity measures. Analysis of Molecular Variance (AMOVA) was performed using the software Arlequin ${ }^{\oplus}$ ver. 3-5.2.2 (Excoffier et al. 2005). A matrix of pairwise genetic differentiation measures between all populations pairs was computed. For genetic differentiation among beech populations, pairwise $\mathrm{F}_{\mathrm{ST}}$ 's were computed using the same software. The significance of the $F_{\text {ST }}$ statistics was tested by 10,000 permutations. The graphical representations of all pairwise $F_{S T}$ were done using the Rfunction of the package "pairFstMatrix.r" (Schneider et al. 2000) implemented in Arlequin via Rcmd (Fig. 2). An Unweighted Pair Group Method with Arithmetic Mean (UPGMA) clustering was computed with 100 bootstrap replications, based on Nei's standard genetic distance (Nei 1987) using the software Populations ver. 1.2.31 (Langella 2000) and TreeView ver. 1.6.6 (Page 2001).

\section{Genetic assignment}

The Bayesian clustering method implemented in the software STRUCTURE ver. 2.3.3 (Pritchard et al. 2000) was used to genetically assign individuals to clusters. Sim- ulations were run for 100,000 steps following a burn-in period of 50,000 steps, considering values of $K$ (number of clusters) from one to 10, with 3 replications for each value of $K$. The analysis was performed using admixture, correlated allele frequencies and no prior information on sampling location. The number of population clusters was estimated using $\Delta K$ parameter according to Evanno et al. (2005) using the STRUCTURE HARVESTER program (Earl \& Von Holdt 2012).

\section{Bottleneck analysis}

The software BOTTLENECK (Cornuet \& Luikart 1996) was used to test for recent change in population size. We tested all beech populations for a bottleneck signature under the stepwise mutation model (SMM), infinite alleles model (IAM) and two phase model (TPM). We tested the significance levels using 1000 simulation iterations and both Wilcoxon's signed rank test and standardized differences test.

\section{Results}

\section{Within population genetic diversity}

Eight to 22 alleles were observed per locus, with a total of 98 alleles across all populations and loci. Private alleles (6) were found in a single peripheral population ( $P$ STA). Five private alleles were detected in the core populations, as follows: three in CAPU, one allele in C-HUE and one in C-VRA. Most of the private alleles except for one (Fir65-183bp) in population P-STA were rare $(p<0.05)$. The values for the basic statistics of genetic diversity are listed in Tab. 2. Only two parameters showed significant differ- 
Tab. 2 - Basic genetic statistics averaged across seven microsatellite loci for each population and group (peripheral and core). $(\mathrm{N})$ : sample size; $\left(\mathrm{N}_{\mathrm{a}}\right)$ : mean number of alleles per locus; $\left(\mathrm{N}_{\mathrm{e}}\right)$ : number of effective alleles; $\left(\mathrm{A}_{R}\right)$ : allelic richness; $\left(\mathrm{H}_{\mathrm{o}}\right)$ : observed heterozygosity; $\left(\mathrm{H}_{\mathrm{e}}\right)$ : gene diversity; $(\mathrm{F})$ : heterozygote deficit; (SE): standard error.

\begin{tabular}{|c|c|c|c|c|c|c|c|c|}
\hline Population & & $\mathrm{N}$ & $\mathrm{N}_{\mathrm{a}}$ & $\mathrm{N}_{\mathrm{e}}$ & $A_{R}$ & $\mathrm{H}_{\mathrm{o}}$ & $\mathrm{H}_{\mathrm{e}}$ & $F$ \\
\hline P-MAC & & 85.7 & 9.14 & 4.61 & 6.697 & 0.686 & 0.718 & 0.041 \\
\hline P-SNA & & 34.1 & 7.57 & 4.56 & 6.603 & 0.641 & 0.728 & 0.116 \\
\hline P-STA & & 46.4 & 9.57 & 4.34 & 7.438 & 0.584 & 0.693 & 0.139 \\
\hline P-TAL & & 19.1 & 5.57 & 2.58 & 5.273 & 0.433 & 0.491 & 0.116 \\
\hline C-HUE & & 48.9 & 10.29 & 3.87 & 7.328 & 0.583 & 0.682 & 0.127 \\
\hline C-APU & & 47.4 & 9.86 & 3.87 & 7.164 & 0.644 & 0.686 & 0.073 \\
\hline C-NOV & & 49.0 & 9.57 & 5.23 & 7.788 & 0.734 & 0.752 & 0.029 \\
\hline C-CAM & & 47.7 & 9.71 & 4.79 & 7.481 & 0.729 & 0.751 & 0.023 \\
\hline C-VRA & & 49.1 & 9.14 & 4.87 & 7.076 & 0.771 & 0.728 & -0.047 \\
\hline \multirow{2}{*}{$\begin{array}{l}\text { Peripheral } \\
\text { populations }\end{array}$} & Mean & 46.3 & 7.96 & 4.02 & 6.503 & 0.586 & 0.658 & 0.103 \\
\hline & SE & 0.6 & 1.15 & 0.81 & 0.107 & 0.071 & 0.073 & 0.055 \\
\hline \multirow{2}{*}{$\begin{array}{l}\text { Core } \\
\text { populations }\end{array}$} & Mean & 48.4 & 9.71 & 4.53 & 7.367 & 0.712 & 0.720 & 0.041 \\
\hline & SE & 0.4 & 1.35 & 0.78 & 0.350 & 0.064 & 0.058 & 0.058 \\
\hline \multirow[t]{2}{*}{ Overall } & Mean & 47.5 & 8.94 & 4.30 & 6.983 & 0.645 & 0.692 & 0.069 \\
\hline & SE & 2.1 & 0.44 & 0.27 & 0.278 & 0.025 & 0.023 & 0.018 \\
\hline
\end{tabular}

Tab. 3 - Analysis of molecular variance (AMOVA) at seven nuclear microsatellite loci. (a): All nine populations; (b): peripheral populations; (c): core populations; (df): degrees of freedom.

\begin{tabular}{clrrcrrr}
\hline Test & Source of variation & df & $\begin{array}{c}\text { Sum of } \\
\text { squares }\end{array}$ & $\begin{array}{c}\text { Variance } \\
\text { components }\end{array}$ & $\begin{array}{c}\text { Percentage } \\
\text { of variation }\end{array}$ & Prob. \\
\hline (a) & Among populations & 8 & 31.432 & 0.03628 & 9.77 & $<0.001$ \\
& Within populations & 899 & 301.231 & 0.33507 & 90.23 & $<0.001$ \\
(b) & Among populations & 3 & 42.349 & 0.13785 & 5.36 & $<0.001$ \\
& Within populations & 406 & 893.919 & 2.43592 & 94.64 & $<0.001$ \\
\hline (c) & Among populations & 4 & 51.026 & 0.10389 & 4.13 & $<0.001$ \\
& Within populations & 493 & 1187.683 & 2.40909 & 95.87 & $<0.001$ \\
\hline
\end{tabular}

ences $(p<0.05)$ between peripheral populations and core populations. Thus, the value of allelic richness $\left(A_{R}\right)$, a genetic parameter without population size bias, and observed heterozygosity $\left(H_{0}\right)$ was higher for core populations than for peripheral ones. Gene diversity and fixation index showed similar values (Tab. 2).

\section{Genetic differentiation among} populations

The analysis of molecular variance (AMOVA) showed that the majority of the variance is within populations (Tab. 3). The differentiation among beech populations was moderate $\left(\mathrm{F}_{\mathrm{ST}}=0.0978\right)$. AMOVA also indicated a slightly higher population differentiation among peripheral populations than among core populations (Tab. 3). The matrix of pairwise $\mathrm{F}_{S T}$ values (Fig. 2) revealed that differentiation between two populations of the same category (e.g., peripheral) was usually lower than differentiation between populations of different categories. The vast majority of the population pairs (more than $89 \%$ ) were significantly differentiated from each other $(p<0.001)$. The strongest differentiation was found between a core (C-APU) and a peripheral $(P-T A L)$ population $\left(F_{S T}=0.4526\right)$. No genetic differentiation was observed between pairs of neighboring peripheral (P-SNA and P-MAC) and core populations (C-VRA and C-MAC).

\section{Population genetic structure}

The dendrogram constructed using Nei's genetic distances between pairs of populations revealed two main groups, one for peripheral and one for core populations, respectively. However, there was a small reliability of nodes (22) based on bootstrap resampling. The most south-eastern peripheral populations (P-MAC and P-SNA) and north-western core populations appear to be very similar (Fig. 3).

The most probable number of genetic clusters identified by the Bayesian analysis, using the ad hoc statistic $\Delta K$, was four (additional data is given in Fig. S1 and Fig. S2 Supplementary material). However, for $K=$ 2 , one cluster corresponds to peripheral populations (green color in Fig. 4) and one to core populations (red color). When having a third cluster $(K=3)$, peripheral populations remain together in one cluster while core populations are divided in two clusters in accordance with their geographic location: within Carpathian region, on the inner side of the South-Eastern Carpathian Mountains (blue color) and outside Carpathian ridge (green color). For $\mathrm{K}=$ 4 , the initial group of peripheral populations is splitted into two clusters: the first cluster corresponds to populations P-MAC and P-SNA, which is in good agreement with the UPGMA dendrogram, and the second one to the rest of peripheral populations (Fig. 4).

\section{Chloroplast DNA analysis}

The three chloroplast microsatellite makers were monomorphic in all populations. Allele $118 \mathrm{bp}, 146 \mathrm{bp}$, and 109bp were observed at ccmp-4, ccmp-7, and ccmp-10, respectively. The same haplotype was observed at the chloroplast level across peripheral and core beech populations, revealing the same geographical origin.

\section{Test for bottleneck signature}

We observed evidence for recent bottle-

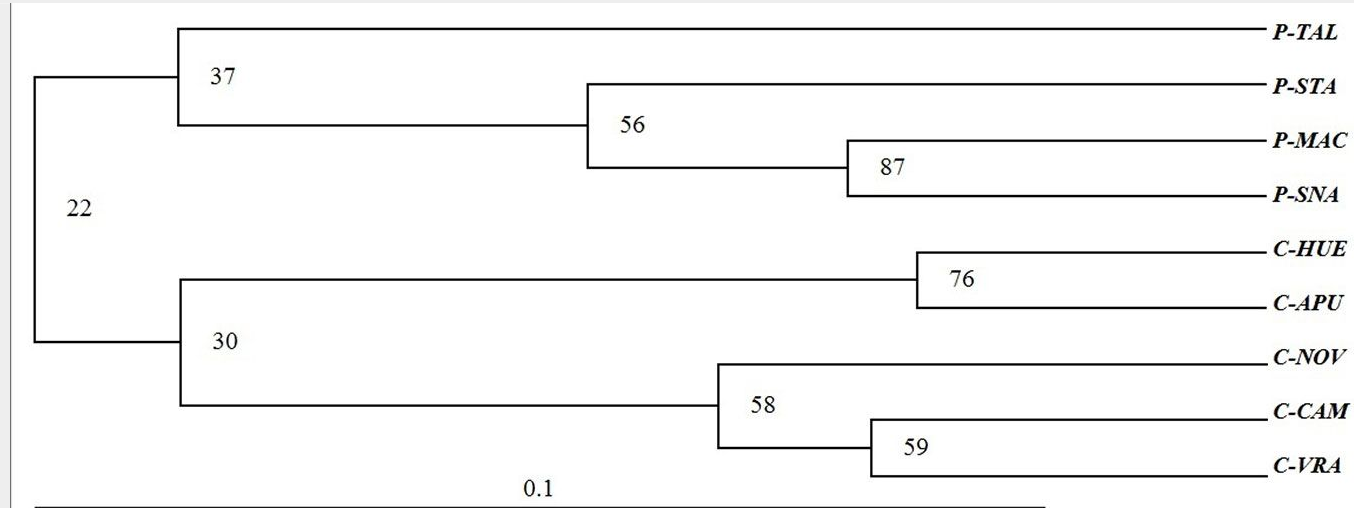

Fig. 3 - UPGMA based on Nei (1987) genetic distance between beech populations. 
Fig. 4 - Genetic structure revealed by seven microsatellite markers. Each individual tree is represented by a thin vertical line which is divided into color segments that are proportional to its membership in the genetic clusters $(k=2$, top panel; $k=3$, middle panel; k=4, lower panel) inferred in the Bayesian analysis. Membership values are averaged across three runs. Populations are separated by a thin black line. $(P)$ : peripheral; $(C)$ : core.

necks or reductions in effective population size in two out of nine beech populations (Tab. 4). The two populations were both classified as peripheral: P-MAC under all three models (IAM, SMM and TPM) and PSNA under the SMM model.

\section{Discussion}

Our set of seven nuclear microsatellite markers indicates a lower level of genetic diversity as measured by allelic richness, which was corrected for variation in sample size, and observed heterozygosity in peripheral, isolated beech populations than in core populations from the continuous Carpathian range. Expected heterozygosity and inbreeding coefficient were similar (no significant differences) between populations classified as peripheral or core based on the beech distribution range in Romania. Similarity in expected heterozygosity but marked differences in observed heterozygosity and inbreeding coefficients between peripheral and core populations were reported in an American conifer species, Sitka spruce, using sequence tagged site loci (Gapare et al. 2005). Very recently, similar levels of genetic diversity between core and peripheral populations were also reported in Scots pine using nuclear microsatellite loci (Wójkiewicz et al. 2016). In terms of private alleles there was nearly a balance between the peripheral and core populations ( 6 vs. 5). However, private alleles were found in only one peripheral population (P-STA) which is located in the south-western part of the country in the proximity of the Balkan Mountains. Surprisingly, no private alleles were found in the other peripheral, isolated populations located much farther from the continuous natural distribution range than the population P-STA. Most of the private alleles detected in core populations are from the two beech populations located in Western Carpathians (Apuseni Mountains) on the

Tab. 4 - Test for recent bottlenecks in beech populations under stepwise mutation model (SMM), infinite alleles model (IAM) and two phase model (TPM). Significance was tested according to the Wilcoxon sign-rank test. Significant $p$-values are indicated with an asterisk $(*)$.

\begin{tabular}{lccc}
\hline Population & SMM & IAM & TPM \\
\hline P-MAC & $0.0016^{*}$ & $0.0078^{*}$ & $0.0016^{*}$ \\
P-SNA & $0.0251^{*}$ & 0.0546 & 0.1093 \\
P-STA & 0.1078 & 0.9375 & 0.1093 \\
P-TAL & 0.0756 & 0.3750 & 0.0546 \\
\hline C-HUE & 0.0718 & 0.6875 & 0.0656 \\
C-APU & 0.0738 & 0.1875 & 0.0790 \\
C-NOV & 0.1093 & 0.1290 & 0.5781 \\
C-CAM & 0.0656 & 0.1056 & 0.6875 \\
C-VRA & 0.1093 & 0.2156 & 0.5781 \\
\hline
\end{tabular}

other side of the Carpathian arc as the majority of the studied populations. The presence of private alleles in Apuseni Mountains might be explained by the existence of a refuge area for beech in that region (Magri et al. 2006). A slightly larger population differentiation was observed among peripheral populations than among core, Carpathian populations, although the latter ones are spread on a larger area and on both sides of the Carpathian mountain chain. This is consistent with the pattern observed in Sitka spruce and may be the result of more substantial gene flow among core populations than among peripheral ones or shared ancestral polymorphism (Gapare et al. 2005). The clustering of populations and the outcomes of the Bayesian analysis partially reflect the geographic relationships between populations. Thus, the two populations from the Western Carpathians are grouped together as well as the three core populations from the other side of the Carpathian Mountains. The cluster with two peripheral populations, P-MAC and P-SNA, has strong bootstrap support (87\%). These two isolated populations might have been the remnants of a migration wave coming from the Car- pathian Mountains towards the Danube valley when the climate conditions were more favorable to beech. Mountain ranges were colonized first and valleys (e.g., Danube valley) were colonized rather late in the Holocene (Magri et al. 2006).

All sampled beech populations share the same chloroplast haplotype. A single haplotype was reported based on the same set of chloroplast microsatellite markers for the Carpathian region in a study on the entire natural distribution range of European beech (Magri et al. 2006). However, no sampling was done at that time in peripheral, isolated lowlands populations from south-eastern Romania. The hypothesis that one of the isolated, peripheral populations (P-MAC) located in the Macin Mountains might originate from a distinct (Balkan) glacial refugium (Diaconeasa 1977), and not from the same putative refuge area as of the Carpathian populations (Moravian area - Magri et al. 2006) is not supported by our data. Numerous other haplotypes were detected based on the same set of three chloroplast microsatellites in the Balkan Mountains and in Greece, but none of these haplotypes were spread northwards (Hatziskakis et al. 2009, Magri 
et al. 2006, Papageorgiou et al. 2008) or observed in our sample. The fact that beech individuals from P-MAC share the same chloroplast haplotype with the Carpathian core populations indicates rather a common geographical origin (Moravian area) of the analyzed populations.

The occurrence of Fagus orientalis and F. $x$ taurica individuals, hybrids between F. sylvatica and $F$. orientalis, were documented in the peripheral Macin (P-MAC) population (Dumitriu-Tataranu \& Ocskay 1952, Oprea et al. 2011). The larger proportion of oriental-like beech individuals suggested a different evolutionary history of this remote beech population. However, first observations made on the site indicated the presence of $F$. sylvatica-like individuals. Moreover, typical ground flora species for beech stands in the nearby Carpathian Mountains were also identified in the beech stand from Macin (Georgescu 1928). Recent statistical analyses of leaf morphology of individual trees sampled in Macin population suggested that most of the individuals are $F$. sylvatica-like and only a few show characters of $F$. orientalis (Ciocîrlan 2014).

A long distance founding event may explain the origin of the beech population ( $P$ $M A C)$ in Macin Mountains. This event implies the existence of bottleneck signatures which was actually found under either IAM or SMM model in population PMAC. Moreover, evidence of a bottleneck was observed in a second peripheral population of very small size (P-SNA). The rest of the peripheral populations may also have experienced bottlenecks, but given the limited sample size of individual trees and loci used in our study, microsatellitebased bottleneck tests often have a limited power to detect recent declines of populations (Peery et al. 2012). An advance of beech front from the Carpathian Mountains towards the south-eastern lowlands (steppe) of Romania along river valleys or during periods of a more humid climate and long distance dissemination events is the most plausible hypothesis for the origin of the current peripheral populations. Actually, what we see at present is only a small portion of the isolated, peripheral beech stands that existed before in the region (Enculescu 1923, Floricica 1973, Georgescu 1928). A forest site with typical ground flora for beech stands but no beech individuals were identified in the Macin Mountains at the beginning of the $20^{\text {th }}$ century. The lack of beech individuals on a typical site might be explained by wood extractions made by the local population (Georgescu 1928). Evidence of remote populations, located several hundred kilometers away from the main species distribution range and which may originate as a result of long distance dissemination events are also found in species of related genera such as in Quercus pubescens at the northern edge of the distribution range (Chybicki et al. 2012).
In conclusion, our data suggest that the existing peripheral beech populations located at the eastern edge of the species distribution range are remnants of a wider array of small beech populations having the same geographical origin as those from the Carpathian Mountain chain. These peripheral populations are less variable than the core populations from the continuous distribution range in terms of allelic richness and observed heterozygosity. Moreover, the population differentiation among peripheral populations is higher than among core populations. This may be mainly explained by bottleneck effects in the past, of which we found evidence in two peripheral populations, and restricted gene flow with the putative origin populations from the Carpathian Mountains. The survival of these peripheral populations under extreme ecological conditions (increased temperatures, prolonged drought) makes them particularly important for research and conservation purposes.

\section{Acknowledgements}

This paper was elaborated during the COST Action FP1202 MaP-FGR. Elena Ciocîrlan was supported by the Sectoral Operational Programme Human Resources Development (SOP HRD), ID134378 financed from the European Social Fund and by the Romanian Government. We are indebted to numerous colleagues from the forest districts across the country for assisting us during the field sampling. We are grateful to an anonymous reviewer for constructive comments on a previous version of the manuscript.

\section{References}

Asuka Y, Tani N, Tsumura Y, Tomaru N (2004). Development and characterization of microsatellite markers for Fagus crenata Blume. Molecular Ecology Notes 4: 101-103. - doi: 10.1046/j. 1471-8286.2003.00583.x

Biris A-I (2014). Fagetele primare din România, o contributie la Patrimoniul Mondial UNESCO [Romania's primary beech forests, a contribution to UNESCO World Heritage]. Bucovina Forestiera 14: 77-85. [in Romanian]

Borovics A, Mátyás C (2013). Decline of genetic diversity of sessile oak at the retracting (xeric) limits. Annals of Forest Science 70: 835-844. doi: 10.1007/s13595-013-0324-6

Channell R, Lomolino MV (2000). Dynamic biogeography and conservation of endangered species. Nature 403: 84-86. - doi: 10.1038/47487 Chhatre VE, Rajora OP (2014). Genetic divergence and signatures of natural selection in marginal populations of a keystone, long-lived conifer, Eastern White Pine (Pinus strobus) from Northern Ontario. PLoS ONE 9 (5): e97291. - doi: 10.1371/journal.pone.0097291

Chybicki IJ, Oleksa A, Kowalkowska K, Burczyk J (2012). Genetic evidence of reproductive isolation in a remote enclave of Quercus pubescens in the presence of cross-fertile species. Plant Systematics and Evolution 298: 1045-1056. - doi: 10.1007/s00606-012-0614-8

Ciocîlan E (2014). Comparative morphological analyses in marginal beech populations. Bulletin of the Transilvania University of Brasov, Forestry, Wood Industry, Agricultural Food Engineering, Series II 7 (56): 7-12.

Comps B, Thiébaut B, Paule L, Merzeau D, Letouzey J (1990). Allozymic variability in beechwoods (Fagus sylvatica L.) over central Europe: spatial differentiation among and within populations. Heredity 65: 407-417. - doi: 10.1038/hdy. 1990.111

Cornuet JM, Luikart G (1996). Description and power analysis of two tests for detecting recent population bottlenecks from allele frequency data. Genetics 144: 2001-2014. [online] URL: http://www.genetics.org/content/144/4/ 2001.short

Diaconeasa B (1977). Valoarea documentara fitoistorica a mlastinii de turba de la MangaliaHerghelie (Jud. Constanta) [The phyto-historical documentary value of the peat bog from Mangalia-Herghelie (Constanta County)]. Contributii Botanice, Gradina Botanica "Alexandru Borza”, Cluj-Napoca, Romania, pp. 41-53. [in Romanian]

Doyle JJ, Doyle JL (1990). Isolation of plant DNA from fresh tissue. Focus 12: 13-15.

Dumitriu-Tataranu I, Ocskay S (1952). Pozitia sistematica si origina fagilor dela Luncavita (Dobrogea de Nord) [The systematic position and origin of the beech trees from Luncavita (Northern Dobrogea)]. Revista Padurilor 1-2: 2531. [in Romanian]

Durand J, Bodenes C, Chancerel E, Frigerio J-M, Vendramin GG, Sebastiani F, Buonamici A, Gailing O, Koelewijn H-P, Villani F, Mattioni C, Cherubini $M$, Goicoechea $P$, Herran A, Ikaran Z, Cabane C, Ueno S, Alberto F, Dumoulin P-Y, Guichoux E, Daruvar A, Kremer A, Plomion C (2010). A fast and cost-effective approach to develop and map EST-SSR markers: oak as a case study. BMC Genomics 11 (1): 570. - doi: 10.1186/1471-2164-11-570

Earl DA, Von Holdt BM (2012). STRUCTURE HARVESTER: a website and program for visualizing STRUCTURE output and implementing the Evanno method. Conservation Genetics Resources 4: 359-361. - doi: 10.1007/s12686-011-95 48-7

Eckert CG, Samis KE, Lougheed SC (2008). Genetic variation across species' geographical ranges: the central-marginal hypothesis and beyond. Molecular Ecology 17: 1170-1188. - doi: 10.1111/j.1365-294X.2007.03659.x

Enculescu P (1923). Zonele de vegetatie lemnoasa din România [The woody vegetation zones of Romania]. Editura Cartea Româneasca, Bucuresti, Romania, pp. 268. [in Romanian] Evanno G, Regnaut S, Goudet J (2005). Detecting the number of clusters of individuals using the software STRUCTURE: a simulation study. Molecular Ecology 14: 2611-2620. - doi: 10.1111/j. 1365-294X.2005.02553.x

Excoffier L, Laval G, Schneider S (2005). Arlequin (version 3.0): an integrated software package for population genetics data analysis. Evolutionary Bioinformatics Online 1: 47-50. [online] URL: http://www.ncbi.nlm.nih.gov/pmc/article s/PMC2658868/

Fady B, Aravanopoulos FA, Alizoti P, Mátyás C, Von Wühlisch $G$, Westergren $M$, Belletti $P$, Cvjetkovic B, Ducci F, Huber $G$, Kelleher CT, 
Khaldi A, Kharrat MBD, Kraigher $\mathrm{H}$, Kramer K, Mühlethaler U, Peric S, Perry A, Rousi M, Sbay H, Stojnic S, Tijardovic M, Tsvetkov I, Varela MC, Vendramin GG, Zlatanov T (2016). Evolutionbased approach needed for the conservation and silviculture of peripheral forest tree populations. Forest Ecology and Management 375: 66-75. - doi: 10.1016/j.foreco.2016.05.015

Floricica N (1973). Prezenta fagului în padurile Ocolului Silvic Snagov [The presence of beech in forests of Snagov Forest District]. Revista Padurilor 88: 367-370. [in Romanian]

Forest Europe/UNECE/FAO (2011). State of Europe's Forests 2011. Status and Trends in Sustainable Forest Management in Europe. Ministerial Conference on the Protection of Forests in Europe, FOREST EUROPE Liaison Unit, Oslo, Norway, pp. 344.

Gapare WJ, Aitken SN, Ritland CE (2005). Genetic diversity of core and peripheral Sitka spruce (Picea sitchensis (Bong.) Carr) populations: implications for conservation of widespread species. Biological Conservation 123: 113-123. - doi: 10.1016/j.biocon.2004.11.002

Georgescu CC (1928). Insulele de fag din Dobrogea [Beech islands of Dobrogea]. Revista Padurilor 4: 231-242. [in Romanian]

Goudet J (1995). FSTAT (version 1.2): a computer program to calculate F-statistics. Journal of Heredity 86: 485-486. - doi: 10.1093/oxfordjournals.jhered.a111627

Gömöry D, Paule L, Shvadchak IM, Popescu F, Sulkowska M, Hynek V, Longauer R (2003). Spatial patterns of the genetic differentiation in European beech (Fagus sylvatica L.) at allozyme loci in the Carpathians and the adjacent regions. Silvae Genetica 52: 78-83. [online] URL: http://www.researchgate.net/publication/2339 93515

Hampe A, Petit RJ (2005). Conserving biodiversity under climate change: the rear edge matters. Ecology Letters 8: 461-467. - doi: 10.1111/j. 1461-0248.2005.00739.x

Hatziskakis S, Papageorgiou AC, Gailing O, Finkeldey R (2009). High chloroplast haplotype diversity in Greek populations of beech (Fagus sylvatica L.). Plant Biology 11: 425-433. - doi: 10.1111/j.1438-8677.2008.00111.x

Langella O (2000). Populations 1.2.31: Population genetic software (individuals or populations distances, phylogenetic trees). Web site. [online] URL: http://bioinformatics.org/ tryphon/ populations

Magri D, Vendramin GG, Comps B, Dupanloup I, Geburek T, Gomory D, Latalowa M, Litt T, Paule L, Roure JM, Tantau I, Van Der Knaap WO, Petit RJ, De Beaulieu JL (2006). A new scenario for the Quaternary history of European beech populations: palaeobotanical evidence and genetic consequences. New Phytologist 171: 199-221. doi: 10.1111/j.1469-8137.2006.01740.x

Nei M (1987). Molecular evolutionary genetics. Columbia University Press, New York, USA, pp. 512.

Oprea A, Sîrbu C, Goia I (2011). The vegetation of the natural reserve Valea Fagilor-Luncavita (Tulcea County, Romania). Contributii Botanice, Gradina Botanica "Alexandru Borza”, Cluj-Napoca XLVI: 17-32.

Page RD (2001). TreeView. Glasgow University, Glasgow, UK, Web site. [online] URL: http://tax onomy.zoology.gla.ac.uk/rod/treeview.html

Pandey M, Rajora OP (2012). Higher fine-scale genetic structure in peripheral than in core populations of a long-lived and mixed-mating conifer - eastern white cedar (Thuja occidentalis L.). BMC Evolutionary Biology 12 (1): 48. - doi: 10.1186/1471-2148-12-48

Papageorgiou AC, Vidalis A, Gailing O, Tsiripidis I, Hatziskakis S, Boutsios S, Galatsidas S, Finkeldey R (2008). Genetic variation of beech (Fagus sylvatica L.) in Rodopi (NE Greece). European Journal of Forest Research 127: 81-88. - doi: 10.1007/s10342-007-0185-3

Pastorelli R, Smulders MJM, Westende Vant WPC, Vosman B, Giannini R, Vettori C, Vendramin GG (2003). Characterization of microsatellite markers in Fagus sylvatica L. and Fagus orientalis Lipsky. Molecular Ecology Notes 3: 76-78. - doi: 10.1046/j.1471-8286.2003.00355.x

Peakall R, Smouse PE (2006). GENALEX 6: genetic analysis in Excel. Population genetic software for teaching and research. Molecular Ecology Notes 6: 288-295. - doi: 10.1111/j.14718286.2005.01155.x

Peery MZ, Kirby R, Reid BN, Stoelting R, DoucetBeer E, Robinson S, Vasquez-Carrillo C, Pauli JN, Palsboll PJ (2012). Reliability of genetic bottle- neck tests for detecting recent population declines. Molecular Ecology 21: 3403-3418. - doi: 10.1111/j.1365-294X.2012.05635.x

Pritchard JK, Stephens M, Donnelly P (2000). Inference of population structure using multilocus genotype data. Genetics 155: 945-959. [online] URL: http://www.genetics.org/conte nt/155/2/945

Schneider S, Roessli D, Excoffier L (2000). ARLEQUIN ver 2.000. A software for population genetics data analysis. Genetics and Biometry Laboratory, Dept. of Anthropology and Ecology, University of Geneva, Geneva, Switzerland.

Stanescu V, Sofletea N, Popescu O (1997). Flora forestiera lemnoasa a Romaniei [Woody forest flora of Romania]. Editura Ceres, Bucuresti, Romania, pp. 451. [in Romanian]

Van Oosterhout C, Hutchinson WF, Wills DPM, Shipley P (2004). Micro-checker: software for identifying and correcting genotyping errors in microsatellite data. Molecular Ecology Notes 4: 535-538. - doi: 10.1111/j.1471-8286.2004.00684.x Vornam B, Decarli N, Gailing O (2004). Spatial distribution of genetic variation in a natural beech stand (Fagus sylvatica L.) based on microsatellite markers. Conservation Genetics 5: 561-570. - doi: 10.1023/B:COGE.0000041025.829 $17 . \mathrm{ac}$

Wójkiewicz B, Litkowiec M, Wachowiak W (2016). Contrasting patterns of genetic variation in core and peripheral populations of highly outcrossing and wind pollinated forest tree species. AoB PLANTS 8: plw054. - doi: 10.1093/aobpla/plw054

\section{Supplementary Material}

Fig. S1 - Estimation of number of clusters $(K)$ from the rate of change in the log probability of data $L(K)$ between successive $K$ values, as measured by $\Delta K$.

Fig. S2 - Number of clusters (K) derived from the Bayesian analysis implemented in STRUCTURE software.

Link: Ciocirlan_2446@supploo1.pdf 